Original Research Paper

\title{
Solid Waste Disposal and its Impact on Surrounding Environment of Matuail landfill Site, Dhaka, Bangladesh
}

\author{
${ }^{1}$ Md. Faruque Hossain, ${ }^{2}$ Esrat Jahan, ${ }^{2}$ Zakia Parveen, ${ }^{1}$ S. Mosaddeq Ahmed and ${ }^{3}$ Md. Jamal Uddin \\ ${ }^{1}$ American International University-Bangladesh, Kuratoli Road, Kuril, Dhaka 1229, Bangladesh \\ ${ }^{2}$ Department of Soil, Water and Environment, University of Dhaka, Dhaka 1000, Bangladesh \\ ${ }^{3}$ Coppin State University, Department of Natural Sciences, Center for Nanotechnology, Baltimore, MD, USA
}

Article history

Received: 13-08-2018

Revised: 01-10-2018

Accepted: 14-11-2018

\section{Corresponding Author:}

Md. Faruque Hossain

American International

University-Bangladesh,

Kuratoli Road, Kuril, Dhaka

1229, Bangladesh

Tel: 8820865,9890804

Cell: +8801759316682

Fax: +88-02-8813233

Email: mfhossain@aiub.edu hossainfaruque@hotmail.com

\begin{abstract}
An investigation was conducted to assess the impact of solid waste disposal on surrounding environment of Matuail landfill site of Dhaka city. Three different locations such as current dumping, abandoned and its surrounded agricultural areas of Matuail landfill were selected for soil and plant samples, leachate from active dumping and fish samples from treated leachate pond. The $\mathrm{Cu}, \mathrm{Zn}$ and $\mathrm{Pb}$ concentrations were high in the dumping (360 $\mu \mathrm{g} \mathrm{g}^{-1} \mathrm{Cu}, 806 \mu \mathrm{g} \mathrm{g}^{-1} \mathrm{Zn}$ and $\left.382 \mu \mathrm{g} \mathrm{g}^{-1} \mathrm{~Pb}\right)$ and abandoned $\left(199 \mu \mathrm{g} \mathrm{g}^{-1}\right.$ $\mathrm{Cu}, 452 \mu \mathrm{g} \mathrm{g}^{-1} \mathrm{Zn}$ and $\left.519 \mu \mathrm{g} \mathrm{g}^{-1} \mathrm{~Pb}\right)$ areas that exceeded the permissible limits. The heavy metal concentrations in plant samples did not show any significant contamination except $\mathrm{Cu}, \mathrm{Zn}$ and $\mathrm{Pb}$ that also exceeded the permissible limits. On the other side, the organic matter and nutrient concentrations such as $\mathrm{N}, \mathrm{P}, \mathrm{K}$ and $\mathrm{S}$ of both soil and plant samples are within desirable value in the studied area. The concentrations of DO, BOD, COD and TDS of the untreated leachate were found $1.34 \mathrm{mg} \mathrm{L}^{-1}, 96 \mathrm{mg} \mathrm{L}^{-1}, 1343 \mathrm{mg}$ $\mathrm{L}^{-1}$ and $7120 \mathrm{mg} \mathrm{L}^{-1}$, respectively that exceeded inland surface water standard but after treatment the concentrations of DO, BOD and TDS in the treated leachate pond were found within the permissible limit. The presence of heavy metal in leachate is not contaminated as it is below the toxic limit. The bioaccumulation of fish from treated pond is extremely high of $\mathrm{Fe}, \mathrm{Mn}, \mathrm{Pb}$ and Ni that exceeded the WHOs permissible limit.
\end{abstract}

Keywords: Solid Waste Disposal, Leachate, Environment, Contaminated, Matuail Landfill

\section{Introduction}

Rapid growth of industries, lack of financial resources, inadequate trained manpower, inappropriate technology and lack of awareness of the community are the major constraints of solid waste management for the fast-growing metropolis of Dhaka (Zahur, 2007; Jahan et al., 2016). This waste comprises of $46.8 \%$ domestic, $21.8 \%$ street sweeping, $19.2 \%$ commercial, $12.9 \%$ industrial and $0.5 \%$ clinical wastes (Salam, 2001). Along with other waste disposal option such as recycling, combustion and composting; landfill is the most preferred option in Bangladesh, because of its simple and easy operation, low cost, less technological involvement and comfort of implementation. Matuail landfill is one of the largest waste dumping sites in Dhaka city.
Decomposed solid waste has both positive and negative impact on the environment. Solid waste contains significant quantity of degradable organic matter which may rich the nutrient status of soil. To illustrate, if they are properly managed by segregating the waste according to their source it can be used on agriculture after composting (Singh and Mahour, 2012). Conversely, if these wastes cannot be controlled in proper manner, then they can bring detrimental effects on surrounding environment including soil, surface and ground water. The soil becomes contaminated by the toxicity of the constituents of wastes, as a result the natural composition of soil is disturbed, which may spoil the top soil and pollutes the sub soil. Leachate from decomposed solid waste conveys heavy metals such as $\mathrm{Fe}, \mathrm{Cu}, \mathrm{Cd}, \mathrm{Ni}, \mathrm{Pb}, \mathrm{Zn}$ etc. and toxic chemicals (Haque et al., 2013). If the 
water source is mixed with the leachate it becomes polluted and will be threaten to water and aquatic life. Usually the adjacent areas of the dumping site are used as cropping field by the local people and in this way hazardous substances may be accumulated by the plant from the decomposed waste and leachate from the dumping site. After dumping the waste under soil, the hazardous volatile organic compound may causes detrimental effects on the health of the people living around the disposal site of the solid wastes.

Several studies have been carried out to quantify the contamination of soil, surface and ground water in the dumping waste at Matuail landfill site (Mamtaz and Chowdhury, 2008; Azim et al., 2011; Haque et al., 2013) but very little is known about the nutrient status and bioaccumulation of heavy metal in plant and aquatic life at the site. Therefore, the current research objective is to know the nutrient and heavy metal concentration of waste and their impact on the surrounding environment; which will help to find out a way of reusing the decomposed wastes in future.
Overall the proposed research objective is to investigate and quantify the soil, plant, leachate, sediment and fish sample in and around the solid waste dumping site.

\section{Materials and Methods}

Matuail landfill site is located on the north of DhakaDemra highway which lies between latitude $23^{\circ} 42.97^{\prime}$ and $23^{\circ} 43.35^{\prime} \mathrm{N}$ and longitude $90^{\circ} 26.83^{\prime}$ and $90^{\circ} 27.2^{\prime} \mathrm{E}$. Approximately 1800 to 2000 tons of waste is coming here every day and the manner of disposal is simply dumping and spreading of waste. It is a semi-aerobic landfill which is in pipe system, half circle of it is solid in lower part and upper half is perforated where natural air is passed by. Leachate from dumping site is stored in leachate pond, which is treated with lime, $\mathrm{FeSO}_{4}$, polymer etc. and stored in another pond (treated leachate pond) then discharged. Some fishes are cultured in treated pond. AGIS-GPS based location map of Matuail landfill site is shown in Fig. 1.

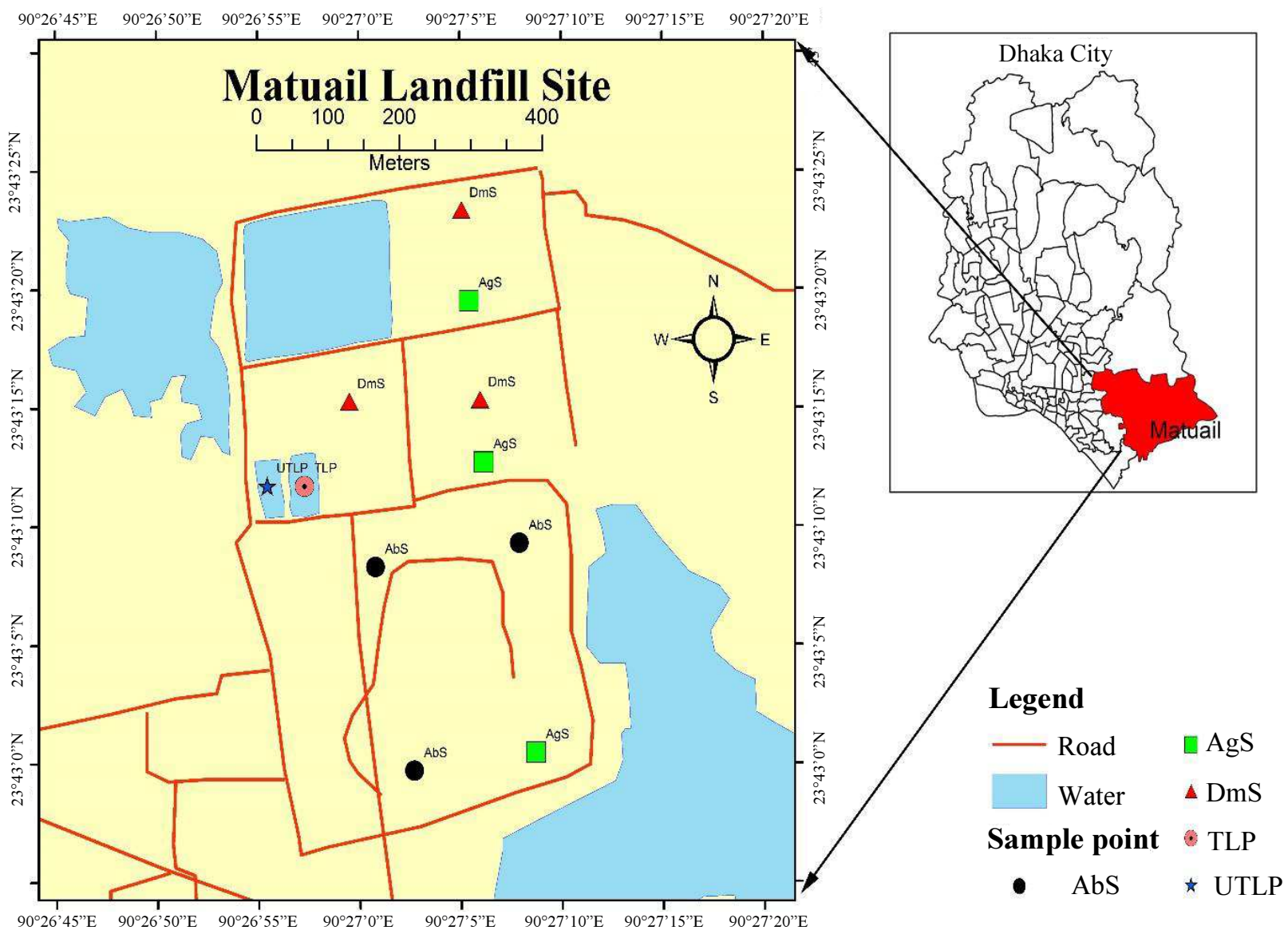

Fig. 1: GIS-GPS based location map of matuail waste disposal site in Dhaka City 
Soil samples were collected from three areas i.e., abandoned landfill area (AbS; in this area dumped waste had been covered with soil to close the site), dumping area (DmS; consists of partially decomposed waste after removing the upper waste part) and surrounded agricultural area (AgS; surrounded area of the landfill used for agriculture). The composite soil samples were collected at $0-15 \mathrm{~cm}$ depth by the Soil Survey Staff (USDA, 1951). Leachate samples were collected from both treated (TLP) and Untreated Leachate Ponds (UTLP) and discharged path of treated leachate waste-water i.e., used for irrigation (IL). Composite plant samples were also collected from each area. Tilapia fish (Oreochromis niloticus) (TPF) samples were collected from the treated pond at the sites. Soil, plant and fish samples were dried, ground and sieved for chemical analysis.

For determination of total $\mathrm{N}$ of soil, plant, leachate and fish samples Kjeldahl method was used (Jackson, 1962). Total concentration of $\mathrm{P}, \mathrm{K}, \mathrm{S}, \mathrm{Fe}, \mathrm{Mn}, \mathrm{Cu}, \mathrm{Zn}$, $\mathrm{Pb}, \mathrm{Cd}$ and $\mathrm{Ni}$ in soil, plant, leachate and fish were analyzed by digesting soil with aqua-regia at a ratio of 1 : 10, digesting leachate with concentrated nitric acid, digesting plant and fish with nitric acid followed by perchloric acid. Total phosphorus was estimated colorimetrically using a spectrophotometer by developing yellow color with vanadomolybdate, total potassium by flame photometer and total sulfur by turbidimetric method using spectrophotometer, available $\mathrm{N}, \mathrm{P}, \mathrm{K}$ and $\mathrm{S}$ in soil by $1 \mathrm{~N} \mathrm{KCl}$, Bray and Kurtz solution, 1N ammonium acetate and Morgan's solution, respectively were used as an extracting agent (Jackson, 1962). Soil was extracted by using $1 \mathrm{~N} \mathrm{HCl}$ with a ratio of 1:33.33 in case of available $\mathrm{Fe}, \mathrm{Mn}, \mathrm{Zn}, \mathrm{Cu} \mathrm{Pb}, \mathrm{Cd}$ and $\mathrm{Ni}$ determination (Chowdhury et al., 2010). After digestion, the concentrations of $\mathrm{Fe}, \mathrm{Mn}, \mathrm{Cu}, \mathrm{Zn}, \mathrm{Pb}, \mathrm{Cd}$ and $\mathrm{Ni}$ in soil, plant, leachate and fish samples were estimated by Atomic Absorption Spectrophotometer (AAS). The pH, Dissolve Oxygen (DO), Total Dissolve Solid (TDS), Biological Oxygen Demand (BOD) and Chemical Oxygen Demand (COD) of leachate samples were determined following the standard methods (APHA, AWWA and WEF, 2012). The statistical analyses were done using software Stata version 12 .

\section{Results and Discussion}

\section{Physicochemical Properties of Studied Soil Sample in and around the Landfill Site}

The $\mathrm{pH}$ of the studied soil samples is slightly acidic having $\mathrm{pH}$ ranges from 5.9 to 6.7 (Table 1). The slightly acidic nature of $\mathrm{pH}$ might reflect the abundance of organic waste in this site but previous research shows that incoming bio-waste like food waste is characterized by low $\mathrm{pH}$ between 4.7 and 6.1 (Norgaard and Sorheim, 2004). The highest value (17.4\%) of moisture content is recorded in dumping area whereas the lowest value $(5.9 \%)$ is recorded in abandoned area in the studied landfill site.

However, a substantial amount of organic matter is observed in the entire area of the studied landfill site. It is also observed that the OM content in dumping area two times higher than the abandoned area and four times higher than the agricultural area (Table 1), mainly due to the abundance of decomposed household organic waste in the dumping area. The CEC of this studied soil is comparatively higher in dumping area than the other areas such as AbS and $\mathrm{AgS}$ because of high $\mathrm{OM}$ content on the dumping area. This possibly reflects that cations held on the organic matter particles in soils can be replaced by other exchangeable cations that increase the cation exchange capacity of soil.

The maximum value of $\mathrm{N}$ is recorded at the dumping area, whereas the minimum is observed in surrounded area of the landfill. Analysis of variance reveals significant difference of $\mathrm{N}$ within three different areas such as $\mathrm{AbS}, \mathrm{DmS}$ and $\mathrm{AgS}$ of the studied landfill site $(p \leq 0.001)$, due to the variation of organic matter content in those areas. The available $\mathrm{N}$ concentration is also observed high in dumping area than other areas (Fig. 3). The relationship between available soil $\mathrm{N}$ and total $\mathrm{N}$ concentration is found to be significant and positive $\left(\mathrm{r}=0.74^{* * *}\right)$ (Table 2). The available soil $\mathrm{N}$ is significant and positively correlated with OM $\left(\mathrm{r}=0.86^{* * *}\right)$ and CEC $(\mathrm{r}=$ $0.91^{* * *}$ ) (Table 3 ), indicates that $\mathrm{OM}$ is an important regulating factor of the content of available $\mathrm{N}$ in soil.

Table 1: Physicochemical properties of studied soil sample in and around the landfill site

\begin{tabular}{|c|c|c|c|c|c|}
\hline \multirow[b]{2}{*}{ Areas } & \multirow[b]{2}{*}{ Denotation } & \multirow[b]{2}{*}{$\mathrm{pH}$} & \multicolumn{2}{|l|}{$(\%)$} & \multirow[b]{2}{*}{ CEC (meq/100g) } \\
\hline & & & Moisture & $\mathrm{OM}$ & \\
\hline Abandoned & $\mathrm{AbS}$ & $6.1 \pm 0.04$ & $5.9 \pm 0.8$ & $6.4 \pm 0.7$ & $8.2 \pm 0.4$ \\
\hline Dumping & $\mathrm{DmS}$ & $5.9 \pm 0.14$ & $17.4 \pm 1.3$ & $11.9 \pm 1.1$ & $10.6 \pm 0.9$ \\
\hline Surrounded agriculture & $\mathrm{AgS}$ & $6.7 \pm 0.3$ & $9.5 \pm 1.7$ & $3.2 \pm 0.03$ & $8.2 \pm 0.2$ \\
\hline
\end{tabular}


Considerable amounts of $\mathrm{P}$ are found in the studied landfill area. The total and available $\mathrm{P}$ concentrations are highest in dumping area (Fig. 2 and 3) and shows a significant difference in both abandoned and surrounded landfill areas $(p \leq 0.001)$. The available $P$ concentration is low in compare with total $\mathrm{P}$ concentration, may be due to the abundance of $\mathrm{Fe}$ in the landfill site that may fixed the excess P (Jokubauskaite et al., 2015). The relationship between total and available $\mathrm{P}$ is positively significant $(\mathrm{r}$ $\left.=0.86^{* * *}\right)$ (Table 2). Soil available $\mathrm{P}$ shows $\mathrm{a}$ significant and positive correlation with soil OM ( $\mathrm{r}=$ $0.97 * * *)$ and CEC $\left(\mathrm{r}=0.81^{* * *}\right)$ (Table 3$)$. It could reflect that the available $\mathrm{P}$ concentrations are increased with the increasing of CEC and OM.

Table 2: Relationship between total and available nutrient concentrations in soil

\begin{tabular}{|c|c|c|c|c|c|c|c|c|c|c|c|c|}
\hline & & \multicolumn{11}{|c|}{ Total nutrient conc. in soil } \\
\hline & & $\mathrm{N}$ & $\mathrm{P}$ & $\mathrm{K}$ & $\mathrm{S}$ & $\mathrm{Fe}$ & $\mathrm{Mn}$ & $\mathrm{Cu}$ & $\mathrm{Zn}$ & $\mathrm{Pb}$ & $\mathrm{Cd}$ & $\mathrm{Ni}$ \\
\hline $\begin{array}{l}\text { Available nutrient } \\
\text { conc. in soil }\end{array}$ & $\begin{array}{l}\mathrm{N} \\
\mathrm{P} \\
\mathrm{K} \\
\mathrm{S} \\
\mathrm{Fe} \\
\mathrm{Mn} \\
\mathrm{Cu} \\
\mathrm{Zn} \\
\mathrm{Pb} \\
\mathrm{Cd} \\
\mathrm{Ni}\end{array}$ & $0.74 * * *$ & $0.86^{* * *}$ & 0.02 & -0.02 & 0.18 & $0.96^{* * *}$ & $0.99 * * *$ & $0.98^{* * *}$ & $0.99 * * *$ & $0.96^{* * *}$ & $0.86^{* * *}$ \\
\hline
\end{tabular}

Note: $* * *$ indicates $0.1 \%$ level of significance

Table 3: Relationship between soil properties and soil available nutrient concentrations

\begin{tabular}{|c|c|c|c|}
\hline & \multicolumn{3}{|c|}{ Relationship between soil available nutrient and its properties } \\
\hline & $\mathrm{pH}$ & $\mathrm{OM}$ & CEC \\
\hline $\mathrm{N}$ & -0.09 & $0.86^{* * *}$ & $0.91 * * *$ \\
\hline $\mathrm{P}$ & 0.36 & $0.97 * * *$ & $0.81 * * *$ \\
\hline K & $0.59 * *$ & $0.79 * * *$ & $0.47 *$ \\
\hline $\mathrm{S}$ & 0.19 & 0.01 & 0.19 \\
\hline $\mathrm{Fe}$ & 0.25 & -0.03 & -0.03 \\
\hline $\mathrm{Mn}$ & $0.44^{*}$ & $0.68 * * *$ & 0.29 \\
\hline $\mathrm{Cu}$ & 0.26 & $0.86 * * *$ & $0.66^{* * *}$ \\
\hline $\mathrm{Zn}$ & 0.31 & $0.85 * * *$ & $0.66 * * *$ \\
\hline $\mathrm{Pb}$ & $-0.42 *$ & 0.03 & 0.13 \\
\hline $\mathrm{Ni}$ & 0.32 & $0.82 * * *$ & $0.62 * * *$ \\
\hline $\mathrm{Cd}$ & 0.29 & $0.79 * * *$ & $0.60 * * *$ \\
\hline
\end{tabular}

Note: ${ }^{*}, * *, * *$ indicates $5 \%, 1 \%$ and $0.1 \%$ level of significance, respectively

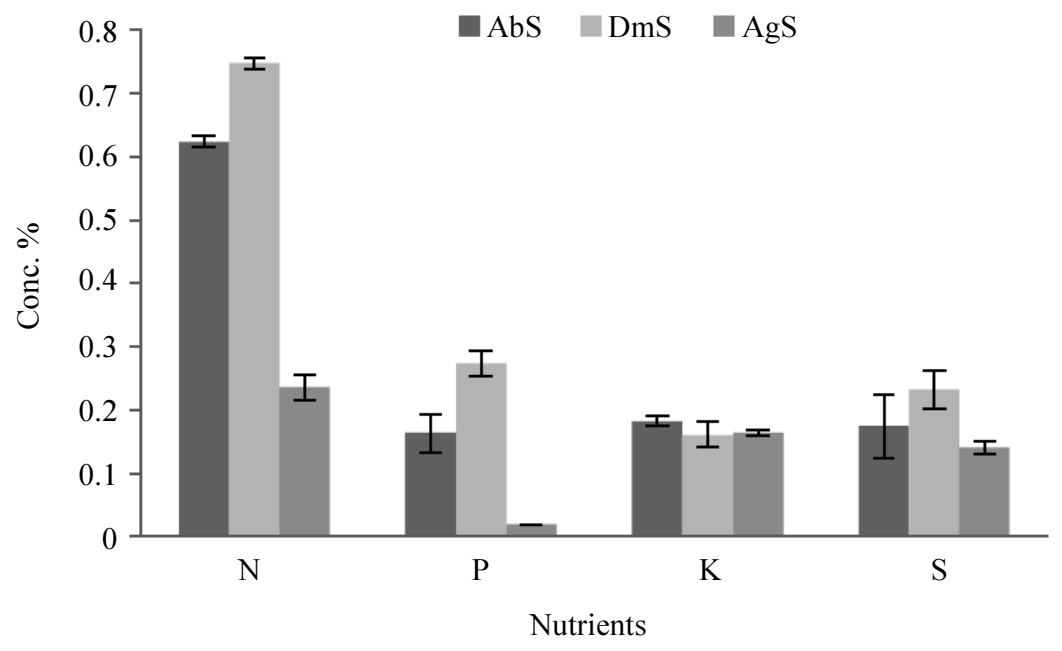

Fig. 2: Concentrations of total nutrient in soil at different areas 


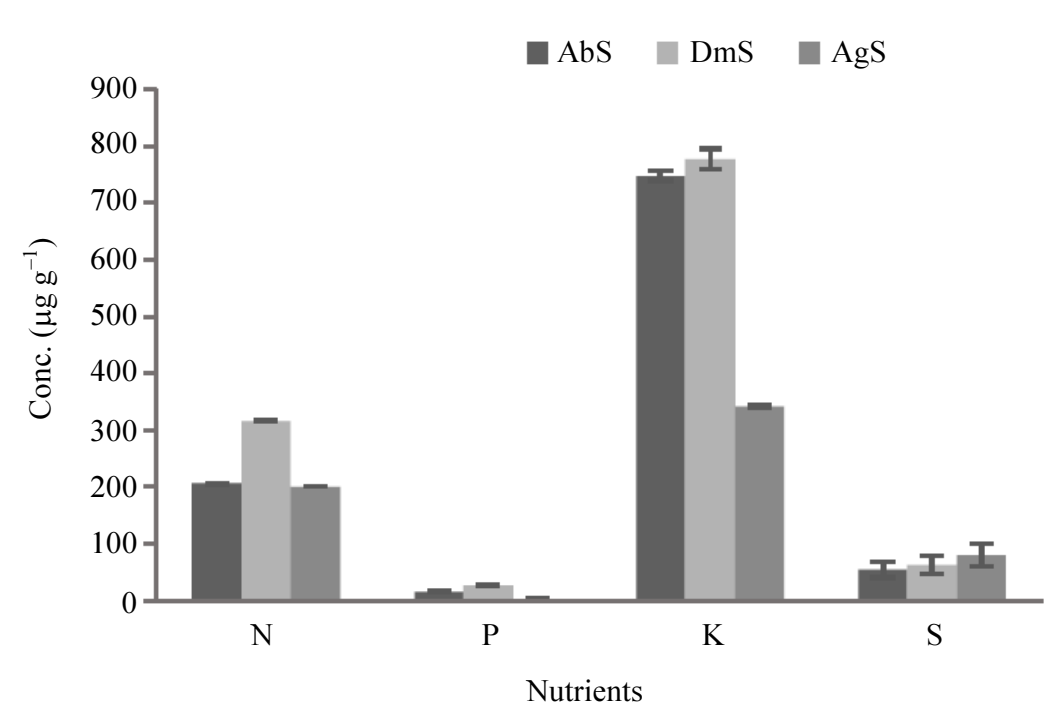

Fig. 3: Concentrations of available nutrient in soil at different areas

The total $\mathrm{K}$ concentration is similar in entire landfill areas (AbS, DmS and $\mathrm{AgS}$ ) and not significantly different from each other. The results shows no clear trend for total $\mathrm{K}$ in three different areas but the available $\mathrm{K}$ concentration is found significantly higher $(\mathrm{p} \leq 0.001)$ in dumping area than surrounded area might be due to the abundance of $\mathrm{K}$ containing waste in dumping area. The available $\mathrm{K}$ concentration is positively correlated with total $\mathrm{K}$ but statistically not significant. Soil available $\mathrm{K}$ is significantly and positively correlated with soil $\mathrm{pH}(\mathrm{r}=$ $\left.0.59^{* *}\right), \mathrm{OM}\left(\mathrm{r}=0.79^{* * *}\right)$ and CEC $\left(\mathrm{r}=0.47^{*}\right)$ (Table 3$)$.

The total $\mathrm{S}$ concentration is significantly varied in three different areas of the landfill site $(\mathrm{p} \leq 0.001)$. The maximum value of $\mathrm{S}$ is recorded at dumping area whereas the minimum is found in both the abandoned area and surrounded agricultural areas (Fig. 2). But the available S concentration was higher in surrounded agricultural area than the DmS and AbS (Fig. 3). In DmS area most of the $\mathrm{S}$ may be present in organically bounded form due to the abundance of organic waste. A negative and very poor relationship is found between total and available S. No significant correlation is observed between soil available $\mathrm{S}$ and soil properties (Table 3). Further work would be needed to establish the cause of this apparent relationship with any other certainty.

The Fe concentration is found highest in abandoned area (Fig. 4) and it is significantly differed $(\mathrm{p} \leq 0.001)$ from both dumping and surrounded areas. The overall $\mathrm{Fe}$ concentrations in the studied landfill site are present within the permissible limit (Kabata-Pendias and Pendias, 2000). Previous study found similar concentration of Fe $\left(12249 \mu \mathrm{g} \mathrm{g}^{-1}\right)$ in decomposed waste but lower concentration of Fe in converted soil $(3411 \mu \mathrm{g}$ $\mathrm{g}^{-1}$ ) at the same landfill site (Haque et al., 2013). The available concentration of $\mathrm{Fe}$ is comparatively higher in the entire landfill site might be due to the low $\mathrm{pH}$, because low $\mathrm{pH}$ increases the availability of $\mathrm{Fe}$. A positive but insignificant relationship is found between total and available Fe $(r=0.18)$ (Table 2). No significant effect is observed for available $\mathrm{Fe}$ in soil properties (Table 3 ).

The total concentration of Mnis significantly higher in both abandoned area and dumping area than surrounded area $(\mathrm{p} \leq 0.001)$ but the average $\mathrm{Mn}$ concentration not exceeded the toxicity level in the studied sample (Kabata-Pendias and Pendias, 2000). A significant positive correlation $\left(\mathrm{r}=0.96^{* * *}\right)$ is existed between the available Mn and total Mn (Table 2). Soil available $\mathrm{Mn}$ is significant and positively correlated with $\mathrm{pH}(\mathrm{r}=0.44 *)$ and $\mathrm{OM}(\mathrm{r}=0.68 * * *)$ (Table 3$)$.

Figure 4 shows that the higher value of $\mathrm{Cu}(422 \mu \mathrm{g}$ $\mathrm{g}^{-1}$ ) in the dumping area than the surrounded area. ANOVA reveals that the value of $\mathrm{Cu}$ in $\mathrm{DmS}$ was significantly differed from the $\operatorname{AgS}(p \leq 0.001)$. The $\mathrm{Cu}$ concentration in abandoned area and dumping area is exceeded the permissible limit (Kloke, 1980), might be due to the presence of $\mathrm{Cu}$ containing waste in this site. A significant and positive correlation is found between the available $\mathrm{Cu}$ and total $\mathrm{Cu}(\mathrm{r}=0.99 * * *)$ (Table 2). Available soil $\mathrm{Cu}$ is significantly and positively correlated with OM $\left(\mathrm{r}=0.86^{* * *}\right)$ and CEC $\left(\mathrm{r}=0.66^{* * *}\right)$ (Table 3$)$.

The concentration of $\mathrm{Zn}$ is recorded highest $(854 \mu \mathrm{g}$ $\mathrm{g}^{-1}$ ) in the dumping area compared with the other two areas (Fig. 4) and significantly differed $(\mathrm{p} \leq 0.001)$ from the both areas. The value of $\mathrm{Zn}$ in $\mathrm{AbS}$ and DmSis exceeded the permissible limit (Kloke, 1980), because of the dumping of $\mathrm{Zn}$ containing waste such as kitchen waste, ash, plastic, paper, dry cell batteries, glass, paint pigment etc. that may contribute to increase the $\mathrm{Zn}$ concentration on that area. A significant positive correlation is observed between soil available $\mathrm{Zn}$ and 
total $\mathrm{Zn}\left(\mathrm{r}=0.98^{* * *}\right)$ (Table 2). The available concentration of $\mathrm{Zn}$ shows positive and significant

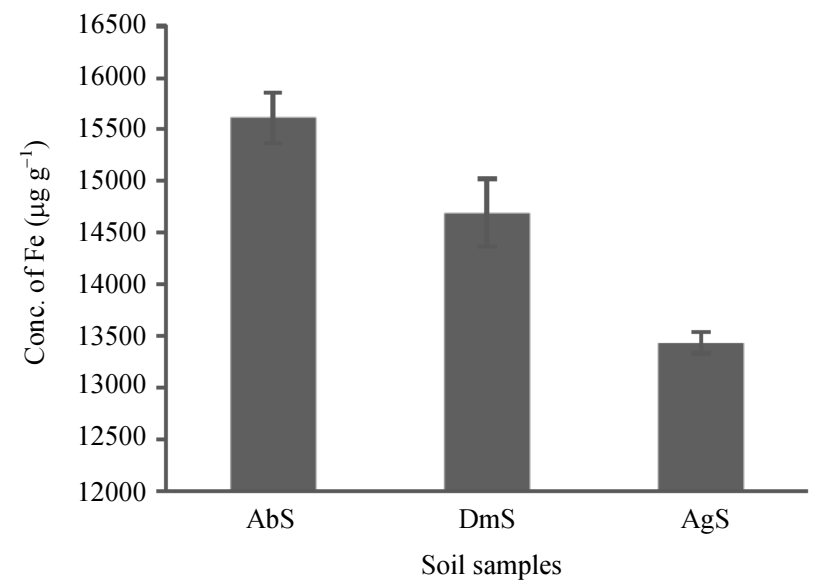

relationship with soil OM $(\mathrm{r}=0.85)$ and $\mathrm{CEC}(\mathrm{r}=$ $0.66^{* * *}$ ) (Table 3).

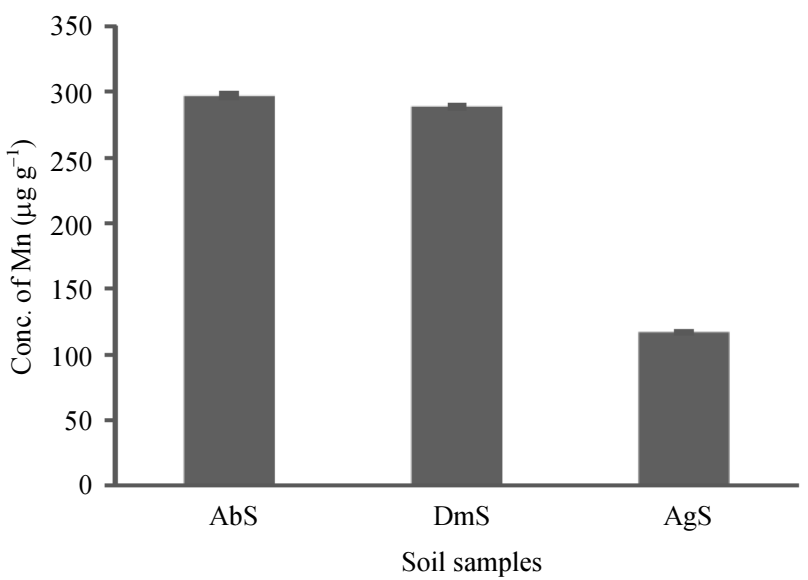

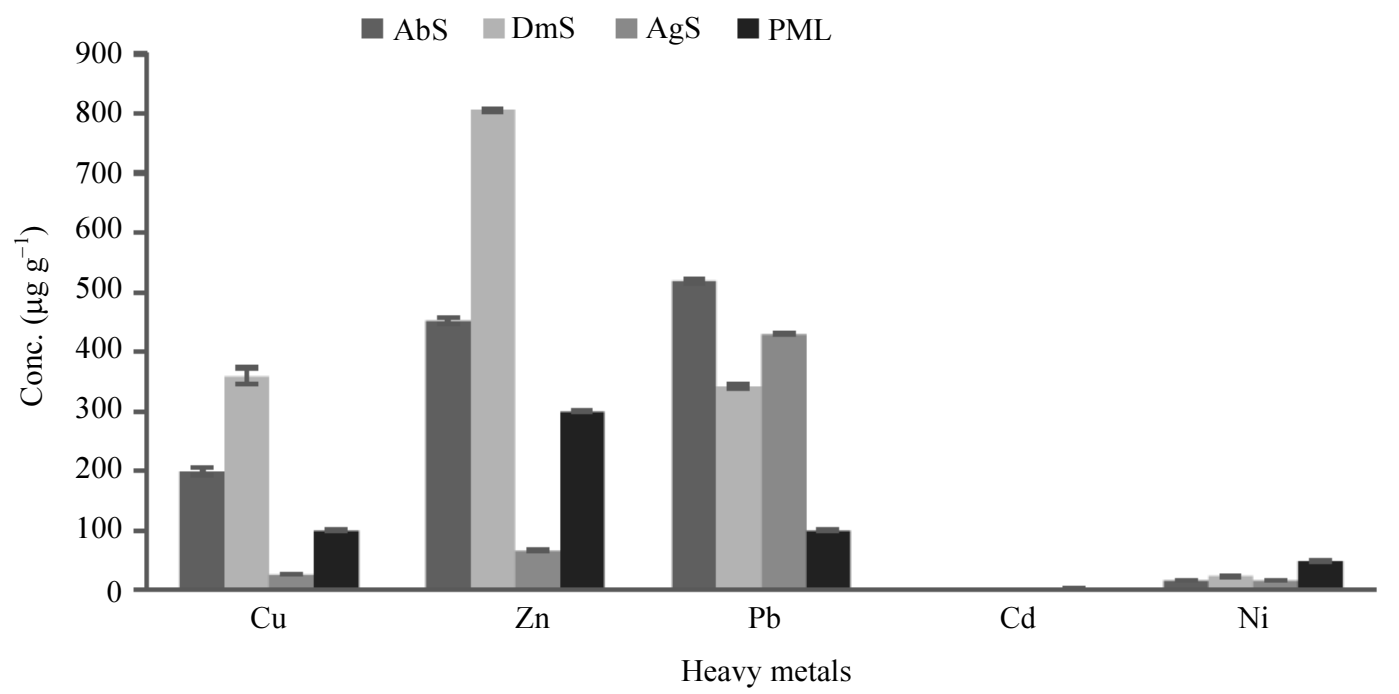

Fig. 4: Average concentrations of total heavy metal in soil at different areas of the landfill site
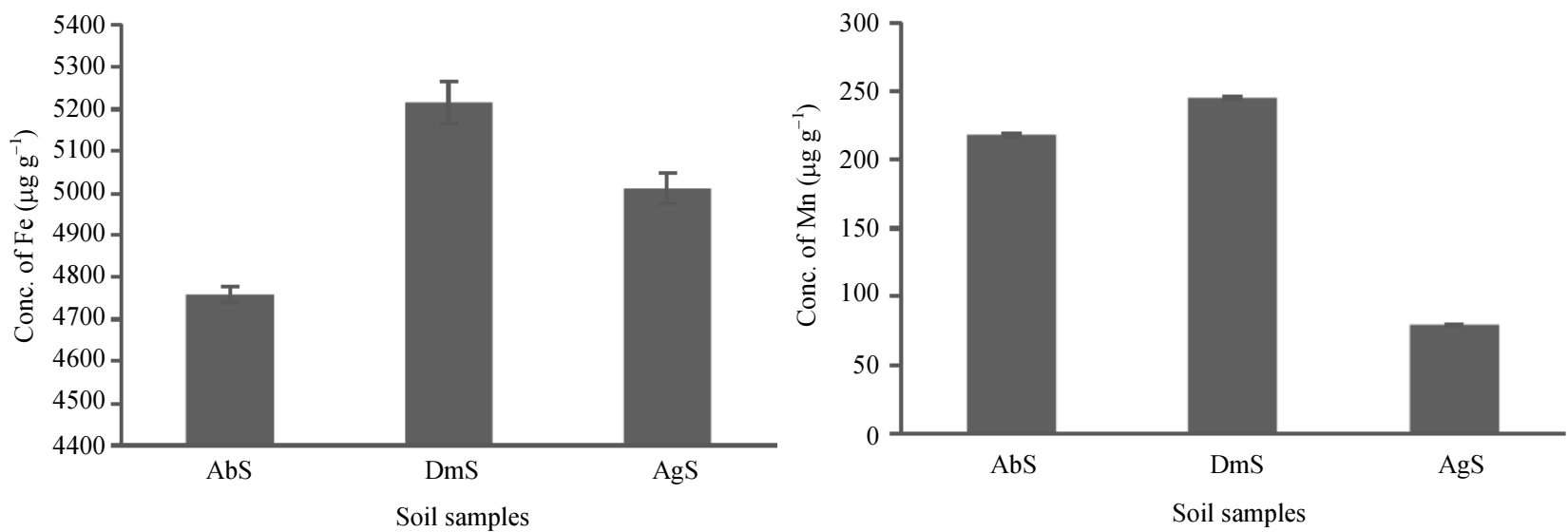


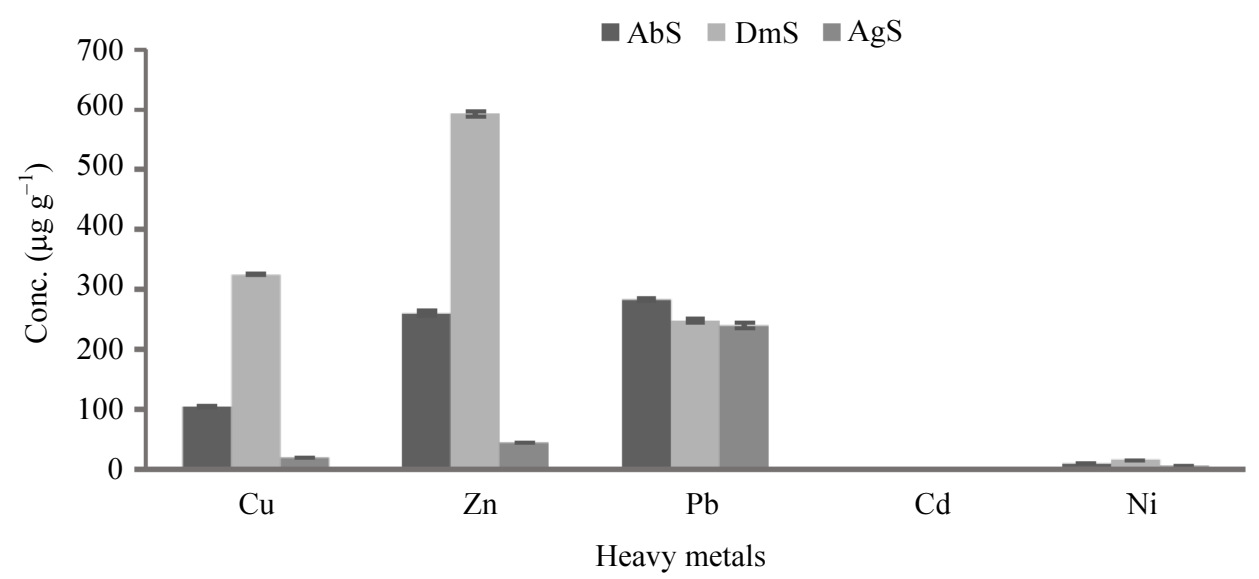

Fig. 5: Average concentrations of available heavy metal in soil at different areas of the landfill site

The average concentration of $\mathrm{Pb}$ in entire studied areas of the Matuail landfill site is exceeded the permissible range (Kloke, 1980). Disposal of different waste material such as electrical goods, electroplating waste, batteries might contribute to increase the $\mathrm{Pb}$ concentration in this site is well agreement with previous study (Mamtaz and Chowdhury, 2008) and also observed a very high concentration of $\mathrm{Pb}$ in converted soil (1449 $\left.\mu \mathrm{g} \mathrm{g}^{-1}\right)$ than decomposed waste (328.26 $\mu \mathrm{g} \mathrm{g}^{-1}$; Fig. 5). The available $\mathrm{Pb}$ concentration of the studied area is observed comparatively high and positively correlated with the total $\mathrm{Pb}(\mathrm{r}=0.99 * * *)$ (Table 2). The low pH might be increased bioavailability of $\mathrm{Pb}$. Soil available $\mathrm{Pb}$ is significantly and negatively correlated with $\mathrm{pH}(\mathrm{r}=-0.42 *)$ (Table 3$)$.

The concentration of $\mathrm{Cd}$ is observed higher $(0.8 \mu \mathrm{g}$ $\mathrm{g}^{-1}$ ) in both abandoned and dumping area than the surrounded agricultural area (Fig. 4 and 5). The value of $\mathrm{Cd}$ is found below the permissible limit (Kloke, 1980) and their concentration is lower than the previous study Haque et al. (2013), who reported that Cd in decompose waste and converted soil is $1.27 \mu \mathrm{g} \mathrm{g}^{-1}$ and $0.61 \mu \mathrm{g} \mathrm{g}^{-1}$, respectively. A significant positive correlation $(\mathrm{r}=$ $\left.0.96^{* * *}\right)$ is found between soil total and available $\mathrm{Cd}$ (Table 2). Soil available $\mathrm{Cd}$ shows a significant and positive correlation with soil OM $(\mathrm{r}=0.79 * * *)$ and CEC $(\mathrm{r}=0.60 * * *)($ Table 3$)$.

The value of $\mathrm{Ni}$ in dumping area is significantly $(\mathrm{p} \leq$ 0.001 ) differed from both abandoned and surrounded agricultural areas and its content did not exceed the permissible limit (Kloke, 1980). Available $\mathrm{Ni}$ is significant and positively correlated with soil $\mathrm{OM}(\mathrm{r}=$ $0.82 * * *)$ and CEC $(\mathrm{r}=0.62 * * *)$ (Table 3$)$.

\section{Nutrient and Heavy Metal Concentrations in Plant Sample}

The nitrogen and phosphorus concentration of plant samples are recorded higher in the dumping area than both abandoned area and the surrounded agricultural area (Fig. 6). It reflects that dumping area contains high concentration of available $\mathrm{N}$ and $\mathrm{P}$ which might be interpreted the high concentration of $\mathrm{N}$ and $\mathrm{P}$ in the plant of dumping area but ANOVA reveals no significant difference of $\mathrm{N}$ and $\mathrm{P}$ concentration between the plants of different areas of the landfill site. The $\mathrm{K}$ concentration in plant of surrounded area is found higher (5.44\%) than the abandoned area (4.76\%) and dumping area (4.01\%). It might be due to the abundance of coarse particles in the dumping area than the surrounding agricultural area that might contribute to leach $\mathrm{K}$ below the plant root zone and discharged leachate in the surrounding vegetation which contain high nutrient.

The concentration of $\mathrm{Fe}$ in plants is lowest $(178 \mu \mathrm{g}$ $\left.\mathrm{g}^{-1}\right)$ in the dumping area whereas highest $\left(837 \mu \mathrm{g} \mathrm{g}^{-1}\right)$ in the abandoned area (Fig. 7), but not exceeded the permissible limit (Kabata-Pendias and Pendias, 2000). In dumping area the partially decomposed solid waste is present in the upper part that may causes root restriction and retards nutrient uptake by plant which might be interpreted the minimum concentration of $\mathrm{Fe}$ in the plant of dumping area. The value of $\mathrm{Mn}\left(83 \mu \mathrm{g} \mathrm{g}^{-1}\right)$ in plant of surrounded agricultural area is found significantly higher than the other areas $(\mathrm{p} \leq 0.001)$, but not exceeded the permissible range (Kabata-Pendias and Pendias, 2000). Further work would be needed to find the causes of this apparent result with any certainty.

The concentration of $\mathrm{Cu}$ in plant is observed more or less similar in the entire area (Fig. 7) and no significant difference is found among them. The $\mathrm{Cu}$ concentration of plant in almost all areas are exceeded the permissible limit (Sauerbeck, 1982), might be due to the high concentration of available $\mathrm{Cu}$ in the soil of entire area. The concentration of $\mathrm{Pb}$ is significantly higher $\left(784 \mu \mathrm{g} \mathrm{g}^{-1}\right)$ in the plant of abandoned area than the other areas $(\mathrm{p} \leq 0.01)$. The overall $\mathrm{Pb}$ concentration in plant samples of the studied landfill site is exceeded the maximum allowable limit (Sauerbeck, 1982). It reflects that the high concentration of $\mathrm{Pb}$ in the soil of landfill area might contribute to increase the $\mathrm{Pb}$ 
accumulation of plant. Fig. 7 illustrates that plants in the surrounded agricultural area accumulated higher $\mathrm{Zn}$ $\left(229 \mu \mathrm{g} \mathrm{g}^{-1}\right)$ than the dumping area. The concentration of $\mathrm{Zn}$ in plant sample of almost all areas is found above the permissible limit (Sauerbeck, 1982) might be due to the abundance of available $\mathrm{Zn}$ in entire soil of the studied area. All the values of $\mathrm{Cd}$ are found below the permissible limit (5-10 $\mu \mathrm{g} \mathrm{g}^{-1}$; Sauerbeck, 1982) in the entire area of the landfill site (Fig. 7). The values of Ni is also observed below the maximum permissible limit (10 $\mu \mathrm{g} \mathrm{g}^{-1}$; WHO, 1989) in different areas of the landfill site. No significant difference is found for $\mathrm{Cd}$ and $\mathrm{Ni}$ in plant of different areas.

\section{Physicochemical Parameters of Leachate at Waste Dumping Site}

The $\mathrm{pH}$ value ranges from 8.00 to 8.23 that confirmed the slightly alkaline in nature of the leachate sample. The measured $\mathrm{pH}$ value shows that all the samples are within the permissible limit given by Department of Environment (DoE) (pH 6 to 9). The maximum DO are recorded in treated leachate pond (7.49 $\left.\mathrm{mg} \mathrm{L}^{-1}\right)$ that while the minimum $\left(1.34 \mathrm{mg} \mathrm{L}^{-1}\right)$ recorded at untreated leachate pond (Fig. 8). The discharged leachate sample shows lower value of DO than the treated leachate sample which is reflected that untreated leachate might be mixed with the treated leachate in the discharged path. Previous study also observed lower value of DO in untreated leachate $(0.9 \mathrm{mg}$ $\left.\mathrm{L}^{-1}\right)$ than the treated leachate $\left(1.4 \mathrm{mg} \mathrm{L}{ }^{-1}\right.$; Azim et al., 2011). According to DoE (2003), the treated leachate is succeeding to keep the DO value within the permissible limit (4.5 to 8). The concentration of BOD in treated leachate sample is present within the permissible limit according to $\mathrm{DoE}\left(50 \mathrm{mg} \mathrm{\textrm {L } ^ { - 1 }}\right)$, whereas the BOD in UTLP is exceeded its limit (Fig. 8).

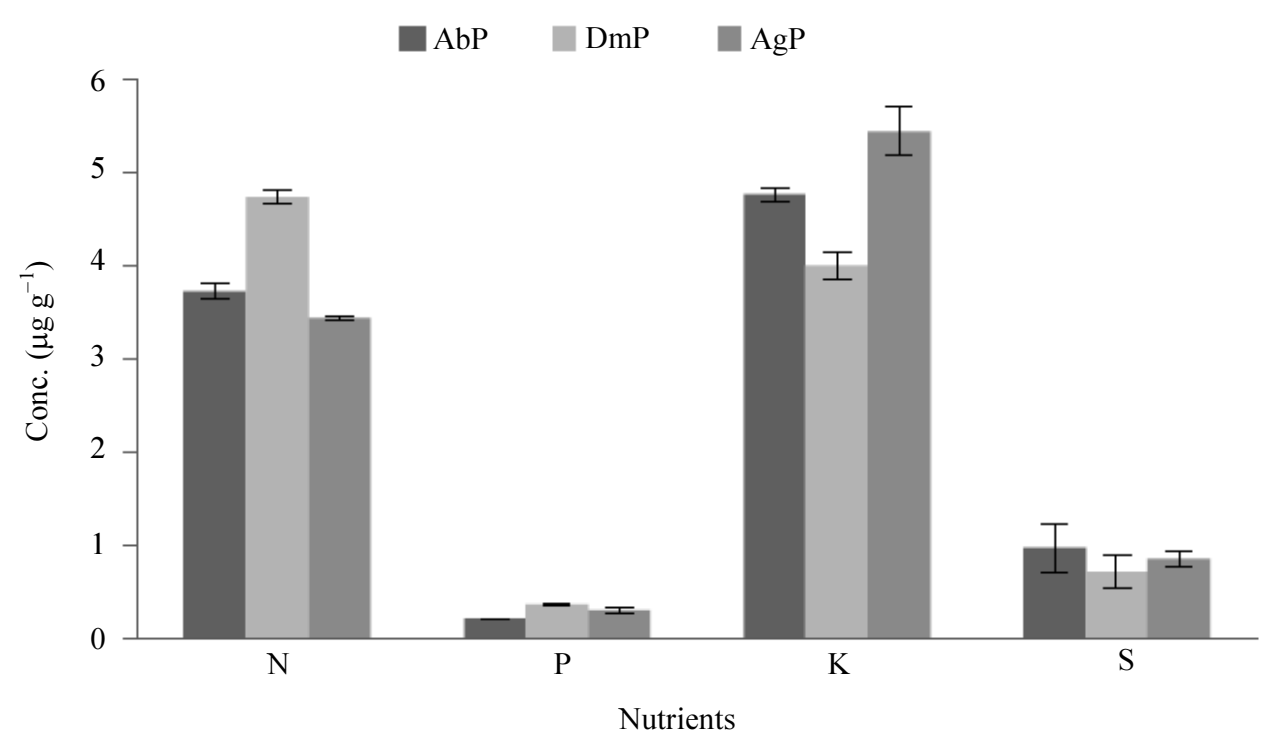

Fig. 6: Concentrations of nutrient in studied plant sample
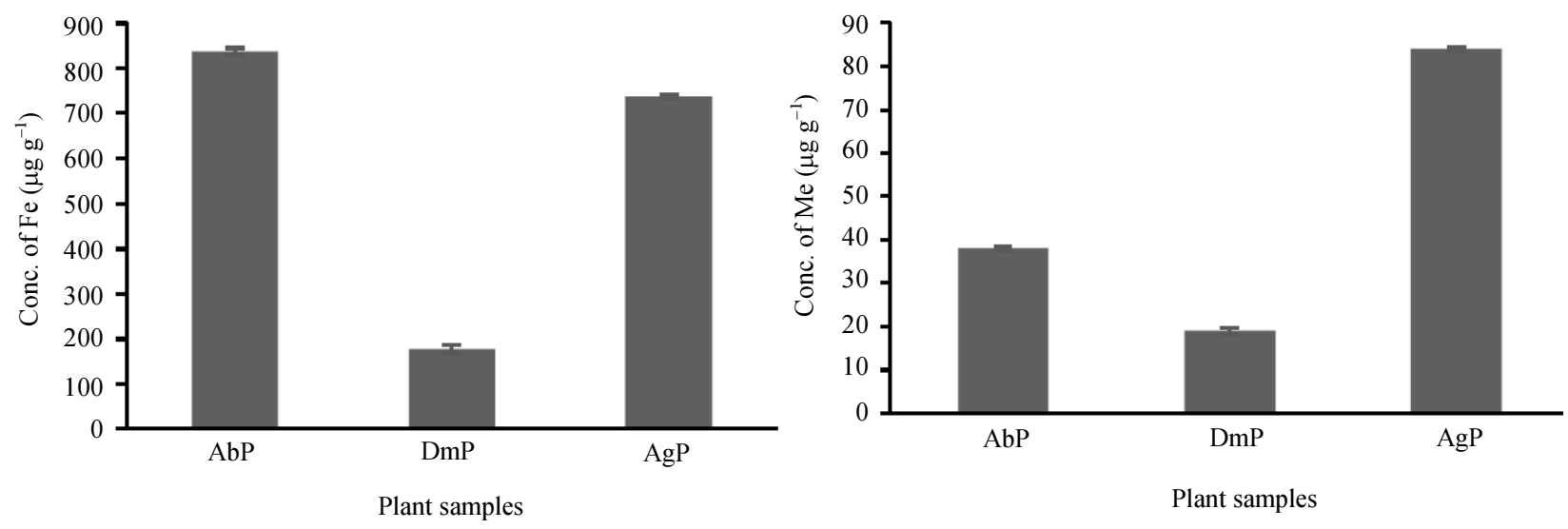


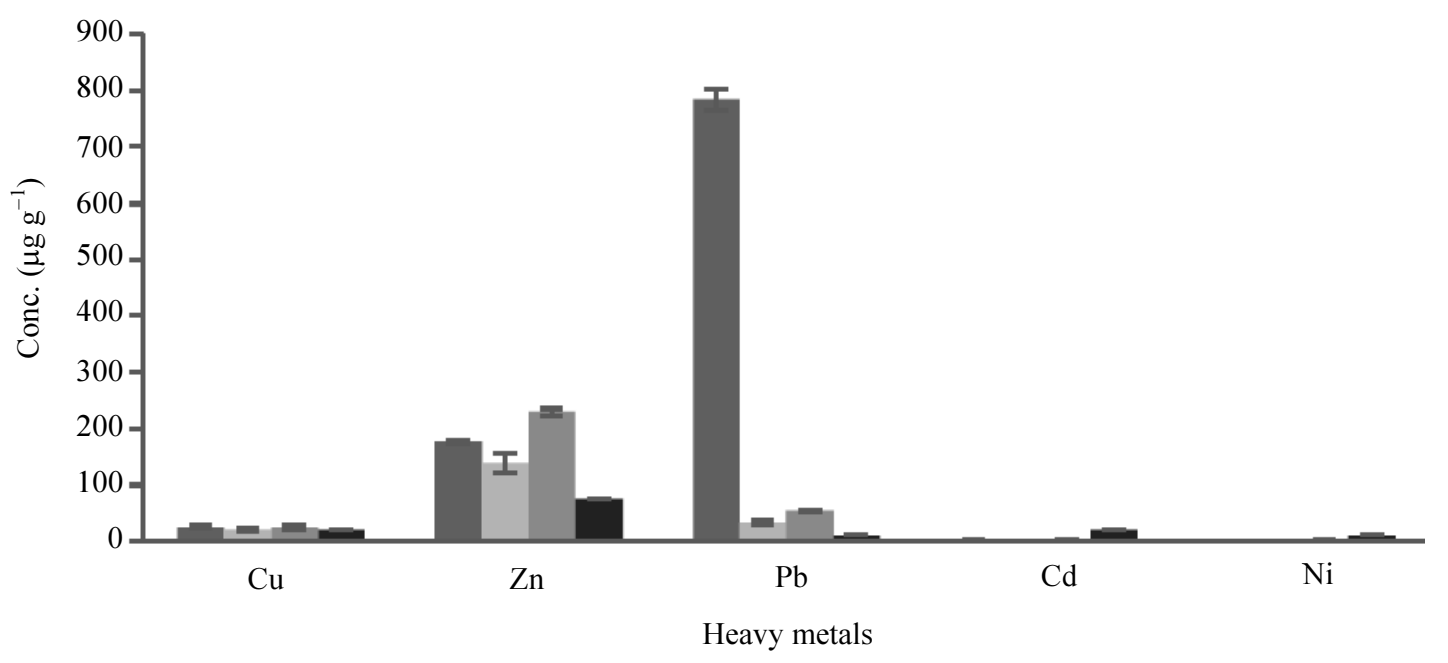

Fig. 7: Concentrations of heavy metal in plant
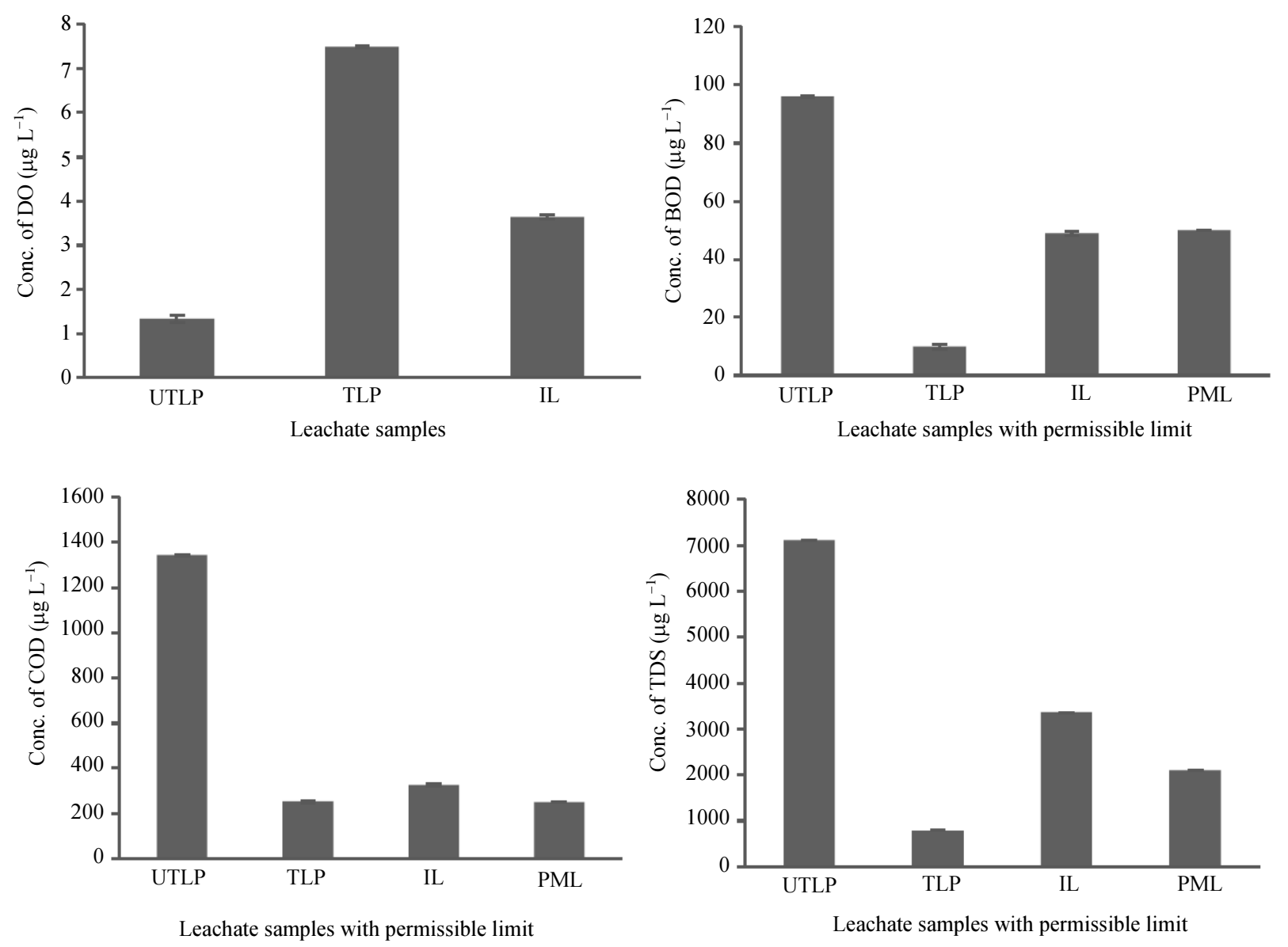

Fig. 8: Concentration of DO, BOD, COD and TDS in different leachate samples

The concentration of COD in untreated leachate sample is supported by another study (Azim et al.,
2011), where COD is found $1630 \mathrm{mg} \mathrm{L}^{-1}$ but in treated leachate the value of COD differed from that study 
(Azim et al., 2011), where COD isfound $1436 \mathrm{mg} \mathrm{L}^{-1}$. The value of COD in different leachate samples is exceeded the permissible limit $\left(250 \mathrm{mg} \mathrm{L}^{-1}\right)$ which may consequently affect the aquatic life. The results show that the TDS value of the treated leachate is below the permissible limit but untreated and discharged leachate lies above the limit (Fig. 8). A similar result well documented for TDS of untreated leachate sample (7178 $\mathrm{mg} \mathrm{L}^{-1}$ ) but for treated leachate sample (Haque et al., 2013), shows higher value of TDS (6637 $\left.\mathrm{mg} \mathrm{L}^{-1}\right)$ compared with the present study $\left(790 \mathrm{mg} \mathrm{L}^{-1}\right)$.

The Fe concentration of all leachate samples are exceeded the standard limit of surface water due to the high concentration of $\mathrm{Fe}$ in the soil of landfill areas. According to DoE (2003), the concentration of $\mathrm{Mn}$ in this study lies within the permissible limit $\left(5 \mathrm{mg} \mathrm{L}^{-1}\right)$ as compared with inland surface water standard (Fig. 9). Hence, leachate samples are not contaminated by $\mathrm{Cu}$ and $\mathrm{Zn}$ due to their presence within the permissible limit. In the present study the leachate sample has shown no appreciable concentration of lead and it was found below the permissible limit (Fig. 9). The $\mathrm{Cd}$ concentration in different leachate samples is found below the detection limit. The concentration of $\mathrm{Ni}$ is lower than the previous study (Azim et al., 2011); where Ni concentration ranges from $1.048 \mu \mathrm{g} \mathrm{g}^{-1}$ (untreated leachate) to $0.097 \mu \mathrm{g} \mathrm{g}^{-1}$ (treated leachate).

\section{Nutrient and Heavy Metal Accumulation in Tilapia Fish from Treated Leachate Pond}

Fish are important aquatic organisms that are used as bio-indicators of aquatic ecosystems for estimation of heavy metal pollution and risk potential for human consumption (Agarwal et al., 2007). Bioaccumulation of metals in fishes takes place directly, from the water by gills and indirectly from food (Barron, 1990).

The Fe accumulation in fish (TPF) collected from treated pond is recorded high $\left(1833 \mu \mathrm{g} \mathrm{g}^{-1}\right)$ that exceeded the permissible limit $\left(100 \mu \mathrm{g} \mathrm{g}^{-1}\right)$ according to WHO (1989). It might be due to the high concentration of $\mathrm{Fe}$ in sediment of treated pond $\left(60237 \mu \mathrm{g} \mathrm{g}^{-1}\right)$. In normal metabolism, fish may uptake heavy metals from water, food or sediment (Irwandi and Farida, 2009). The Mn value in fish sample collected from the treated pond shows higher accumulation of $\mathrm{Mn}$ that is exceeded the permissible limit ( $1 \mu \mathrm{g} \mathrm{g}^{-1}$; WHO, 1989; Fig. 10). It might be due to the high concentration of $\mathrm{Mn}$ in sediment sample in the same pond. The $\mathrm{Cu}$ and $\mathrm{Zn}$ are regulated by physiological mechanisms in most organisms. The accumulation of $\mathrm{Cu}$ and $\mathrm{Zn}$ by the Tilapia fish collected from treated pond, not exceed the recommended limit $\left(30 \mu \mathrm{g} \mathrm{g}^{-1}\right.$ for $\mathrm{Cu}$ and $100 \mu \mathrm{g} \mathrm{g}^{-1}$ for $\mathrm{Zn}$; WHO, 1989). The accumulation of $\mathrm{Pb}$ in the studied fish sample is found high $\left(7.9 \mu \mathrm{g} \mathrm{g}^{-1}\right)$ that exceeded the allowable limit (2 $\mu \mathrm{g} \mathrm{g}^{-1}$; WHO, 1989). Though the $\mathrm{Pb}$ concentration in treated leachate is below the detection level, the high accumulation of $\mathrm{Pb}$ in fish sample might be due to the presence of high concentration of $\mathrm{Pb}$ in the sediment (135 $\left.\mu \mathrm{g} \mathrm{g}^{-1}\right)$. The $\mathrm{Cd}$ concentrations in leachate fish sample from treated pond is below the detection limit but in sediment sample it is $0.2 \mu \mathrm{g} \mathrm{g}^{-1}$ (Table 4). The toxicity of Ni to aquatic life has varied significantly with organism species, $\mathrm{pH}$ and water hardness (Birge and Black, 1980). The accumulation of $\mathrm{Ni}$ in Tilapia fish is $1.28 \mu \mathrm{g} \mathrm{g}^{-1}$ higher than the recommended limit $\left(1 \mu \mathrm{g} \mathrm{g}^{-1}\right.$; WHO, 1989). High concentration of $\mathrm{Ni}$ in Tilapia fish may reflect the substantial amount of $\mathrm{Ni}$ accumulation from sediment through food chain, although this finding needs thorough investigation.

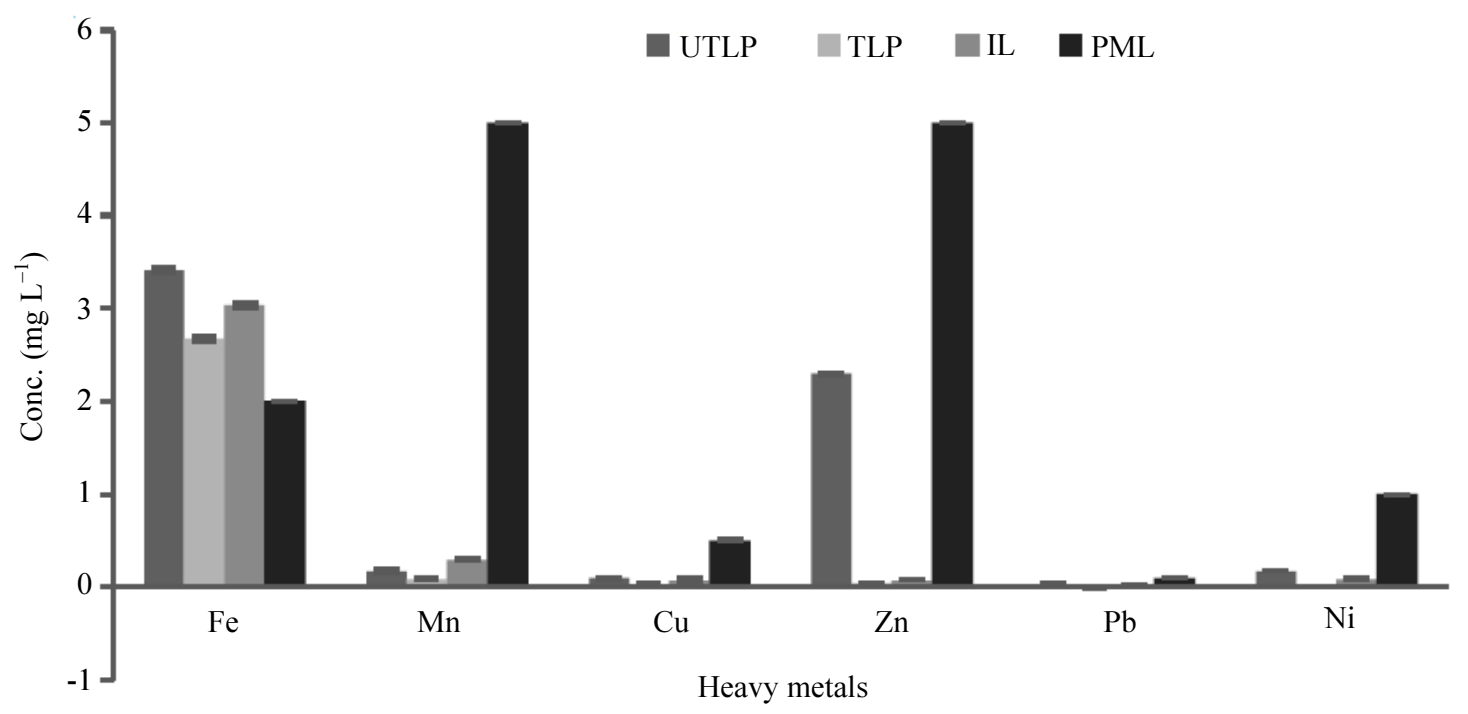

Fig. 9: Concentrations of heavy metal in different leachate samples 


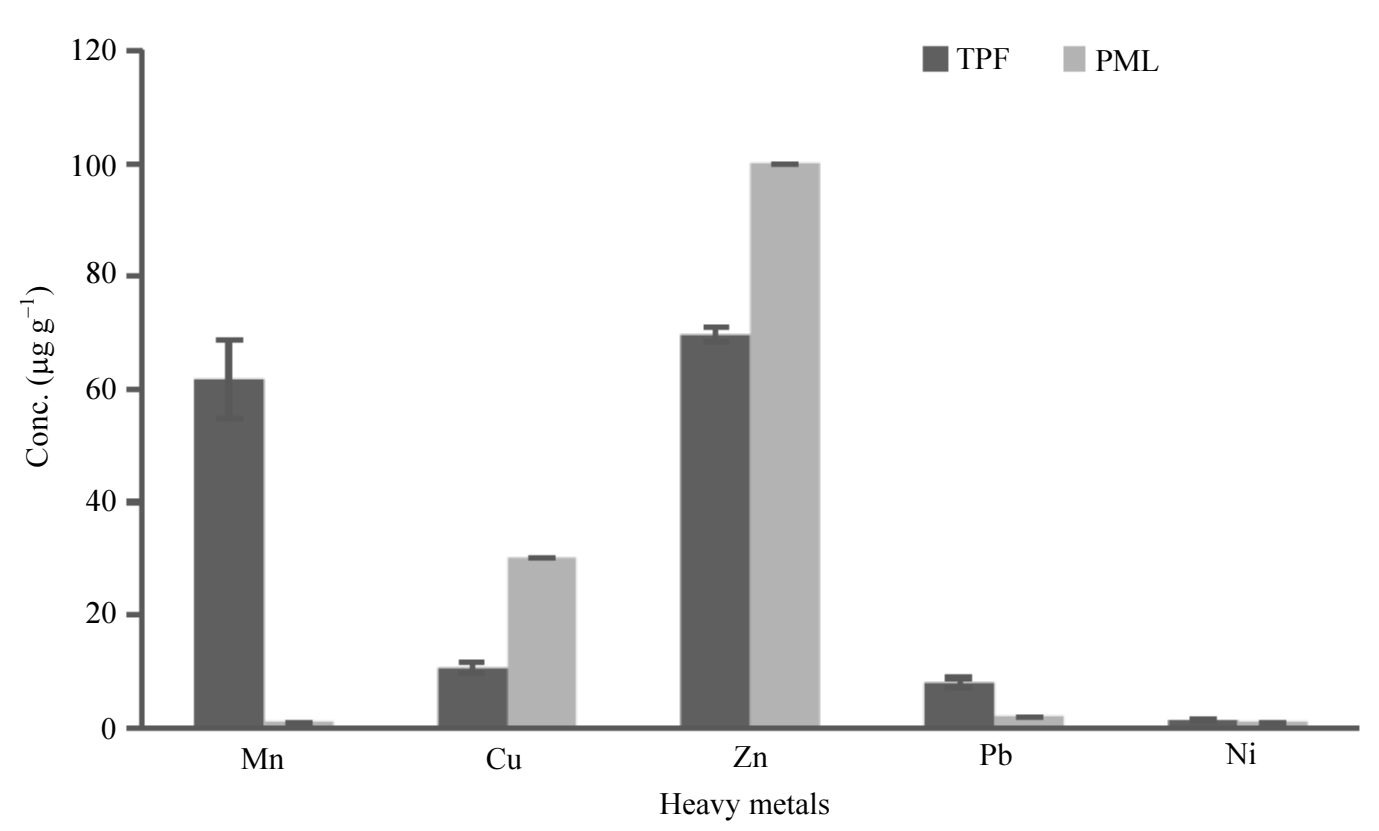

Fig. 10: Heavy metal accumulation in fish from treated leachate pond with their permissible limit

Table 4: Concentrations of $\mathrm{Fe}, \mathrm{Mn}, \mathrm{Cu}, \mathrm{Zn}, \mathrm{Pb}, \mathrm{Cd}$ and $\mathrm{Ni}$ in sediment and fish from treated leachate pond

\begin{tabular}{|c|c|c|c|c|c|c|c|c|}
\hline \multirow[b]{2}{*}{ Sample } & \multirow[b]{2}{*}{ Denotation } & \multicolumn{6}{|c|}{ Concentration $\left(\mu \mathrm{g} \mathrm{g}^{-1}\right)$} & \multirow[b]{2}{*}{$\mathrm{Ni}$} \\
\hline & & $\mathrm{Fe}$ & $\mathrm{Mn}$ & $\mathrm{Cu}$ & $\mathrm{Zn}$ & $\mathrm{Pb}$ & $\mathrm{Cd}$ & \\
\hline Sediment & TPS & $60237 \pm 851$ & $1398 \pm 74$ & $33.1 \pm 9$ & $332 \pm 78$ & $135 \pm 2$ & $0.2 \pm 0.01$ & $23 \pm 4.8$ \\
\hline Tilapia fish & TPF & $1833 \pm 166$ & $61.7 \pm 7$ & $10.6 \pm 0.9$ & $69.7 \pm 9$ & $7.9 \pm 0.8$ & BDL* & $1.28 \pm 0.3$ \\
\hline
\end{tabular}

*BDL=Below Detection Limit

\section{Conclusion}

The results show that the soil of dumping and abandoned landfill area contained significant amount of heavy metals and their concentrations are in the order of $\mathrm{Zn}>\mathrm{Pb}>\mathrm{Cu}>\mathrm{Ni}>\mathrm{Cd}$, where $\mathrm{Pb}, \mathrm{Cu}$ and $\mathrm{Zn}$ exceeded the permissible limit. The surrounded agricultural area of the landfill site contains lower heavy metal concentrations than both dumping and abandoned areas. The dumping area also contains high nutrient and organic matter that may be due to the abundance of decomposed organic waste. Except $\mathrm{Cu}, \mathrm{Pb}$ and $\mathrm{Zn}$, the heavy metal concentrations of plant in entire areas of the landfill sites are below the level of toxicity. However, the nutrient concentrations of plant are present at satisfactory level. The concentrations of TDS, BOD and COD in untreated leachate pond is higher than the DoE recommended inland surface water standard but in treated pond the values of TDS and BOD are within the permissible limit. The $\mathrm{Mn}, \mathrm{Cu}, \mathrm{Pb}, \mathrm{Zn}, \mathrm{Cd}$ and $\mathrm{Ni}$ in leachate samples show no contamination as it is found below the maximum permissible limit. The analysis revealed that the quality of treated leachate sample is succeeded to satisfy the inland surface water quality standard of Bangladesh. The fish and sediment samples collected from the treated leachate pond contain significant amount of heavy metals. The accumulations of $\mathrm{Fe}, \mathrm{Mn}, \mathrm{Pb}$ and $\mathrm{Ni}$ in fish sample are above the permissible limit. The soil, plant, leachate and fish samples collected from the landfill site are rich in both nutrient and some heavy metal concentrations. If the dumping site is properly managed by segregating the waste according to their source, then this waste could be used as compost. Though dumping waste may cause adverse impact on environment, we cannot avoid this because developing countries like Bangladesh land filling is the only way of waste disposal. However, by maintaining disposal sites appropriately with controlled placement and proper treatment of the waste may reduce the adverse impact on agri-environmental eco-systems.

\section{Acknowledgements}

The authors wish to acknowledge that this publication is an output from a project funded bythe Ministry of Science and Technology, Government of Bangladesh for the benefit of the country.

\section{Author's Contributions}

Md. Faruque Hossain: Research plan, Sampling, Laboratory experiments, Supervision, Statistical 
analysis, Interpretation, Manuscript writing and Preparation for publication.

Zakia Parveen: Research plan, Supervision and manuscript review.

Esrat Jahan: Sample preparation, Laboratory experiments and analysis

S. Mosaddeq Ahmed: Sampling, Interpretation of data, Manuscript writing and revision.

Md. Jamal Uddin: Research supervision, statistical analysis and manuscript review.

\section{Declaration of Conflicting Interests}

The authors declare that there is no conflict of interest.

\section{References}

Agarwal, R., R. Kumar and J.R. Behari, 2007. Mercury and lead content in fish species from the river Gomti, Lucknow, India, as biomarkers of contamination. Bull. Environ. Cont. Toxico., 78: 108-112. DOI: $10.1007 / \mathrm{s} 00128-007-9035-8$

APHA, AWWA and WEF, 2012. Standard Methods for Examination of Water and Wastewater. 22nd Edn., Washington DC, pp: 1360.

Azim, M.D., M.M. Rahman, R.H. Khan and A.T.M.M. Kamal, 2011. Characteristics of leachate generated at landfill sites and probable risks of surface and ground water pollution in the surrounding areas: A case study of matuail landfill site. J. Bang. Acad. Sci., 35: 153-160. DOI: 10.3329/jbas.v35i2.9418

Barron, G.M., 1990. Bioconcentration. Will water-borne organic chemicals accumulate in aquatic animals? Environ. Sci. Technol., 24: 1612-1618.

DOI: $10.1021 / \mathrm{es} 00081 \mathrm{a} 001$

Birge, W.S. and J.A. Black, 1980. Aquatic Toxicology of Nickel. In: Nickel in the Environment, John Wiley and Son Inc., USA, pp: 349-366.

Chowdhury, M.T.A., L. Nesa, M.A. Kashem and S.M. ImamulHuq, 2010. Assessment of phytoavailability of $\mathrm{Cd}, \mathrm{Pb}$ and $\mathrm{Zn}$ using various extraction procedures. Pedologist, 53: 80-95.

DoE, 2003. A compilation of environmental laws of Bangladesh. Department of Environment.

Haque, M.A., M.A. Hoque, M.S.A. Modal and M.T. Rahman, 2013. Characterization of leachate and solid waste of Dhaka city corporation landfill site for solid waste stabilization. Am. J. Civil Eng. Arc., 1: 39-42.
Irwandi, J. and O. Farida, 2009. Mineral and heavy metal contents of marine fin fish in langkawi Island, Malaysia. Int. Food Res. J., 16: 105-112.

Jackson, M.L., 1962. Soil Chemical Analysis. 1st Edn., Prentice-Hall Inc., New York, pp: 498.

Jokubauskaitè, I., D. Karčauskienè, Š. Antanaitis, J. Mažvila and A. Šlepetienè et al., 2015. The distribution of phosphorus forms and fractions in retisolunder different soil liming management. Zemdirbyste-Agriculture, 102: 251-256. DOI: $10.13080 /$ z-a.2015.102.032

Jahan, E., A. Nessa, M.F. Hossain and Z. Parveen, 2016. Characteristics of municipal landfill leachate and its impact on surrounding agricultural land. Bangladesh J. Sci. Res., 29: 31-39. DOI: 10.3329/bjsr.v29i1.29755

Kloke, A., 1980. Orientierungsdaten für tolerierbare gesamtgehalte einigerelemente in kulturboden mitt. VDLUFA. Heft., 1-3: 9-11.

Kabata-Pendias, A. and H. Pendias, 2000. Trace Elements in Soils and Plants. 3rd Edn., CRS Press, Boca Raton, London, pp: 312.

Mamtaz, R. and M.H. Chowdhury, 2008. Environmental pollution at solid waste disposal site. Pollut. Res., 27: 207-212.

Norgaard, E. and R. Sorheim, 2004. Measures for the establishment of thermal composting when treating bio-waste, in Norwegian. Norway.

Salam, M.A., 2001. Analysis and design of solid waste management system for a residential zone of Dhaka City. M.Sc. Thesis, Department of Civil Engineering, BUET, Dhaka.

Sauerbeck, D., 1982. Welche Schwermetallgehalte in Pflanzendürfen nicht überschrittenwerden, um Wachstumsbeeinträchtigungen $\mathrm{zu}$ vermeiden, Landw. Forsch. Sonderheft. Kongressband, 39: 108-129.

Singh, B.V. and M. Mahour, 2012. Methane emission estimation from landfill sites. J. Atmos. Environ., 5: 20-22.

USDA, 1951. Soil survey manual. soil survey staff. Bureau of Plant Industry, Soil and Agricultural Engineering, United States Department of Agriculture, Washington.

WHO, 1989. Evaluation of certain food additives and the contaminants mercury, lead, cadmium and nickel. WHO Technical Report.

Zahur, M., 2007. Solid waste management of Dhaka City: Public private community partnership. BRAC Univ. J., 4: 93-97. 